\title{
VOCAÇÃO DE POETA OU DO TRÁGICO COMO TAREFA DA POESIA EM HÖLDERLIN
}

\author{
Solange Aparecida de Campos Costa ${ }^{1}$ \\ Universidade Estadual do Piauí (UESPI) \\ https://orcid.org/0000-0003-2185-7858 \\ E-mail: solange@phb.uespi.br
}

\section{RESUMO:}

Esse artigo examina como se define a questão do trágico para Hölderlin, importante poeta alemão do século XVIII. Em 1804, Hölderlin traduz e comenta as peças Édipo-rei e Antígona de Sófocles. Esse artigo se concentra na investigação sobre o trágico que Hölderlin empreende na terceira parte de suas Observações sobre Édipo, nela surgem elementos que são singulares no seu pensamento, como a cesura, a dupla infidelidade e o afastamento categórico do deus. Esses elementos permitem que Hölderlin trate o tema do trágico a partir de uma visão completamente nova para o seu tempo e que propiciou o surgimento de importantes reflexões posteriores na literatura e na filosofia. Duas são as questões principais que norteiam a argumentação neste artigo: a primeira se refere à acepção singular de Hölderlin sobre os paradoxos que comumente constituem o trágico, como o humano e o divino; a segunda, a análise da tarefa poética da modernidade como tarefa possível para toda e qualquer poesia.

PALAVRAS-CHAVE: Hölderlin; Trágico; Édipo; Poesia.

\section{A POET'S CALLING OR ON TRAGIC AS A TASK OF HÖLDERLIN'S POETRY}

\begin{abstract}
:
This paper examines how the question of the Tragic is defined according to Hölderlin, an important German poet from the XVIII century. In 1804, Hölderlin translates and comments the plays Oedipus the King and Antigone, by Sophocles. This paper focuses on the investigation about the Tragic undertaken by Hölderlin in the third part of his Remarks on Oedipus; in this part, some elements which are singular to his thought come up, such as the Caesura, the Mutual Unfaithfulness and the Categorical Reversal. These elements allowed Hölderlin to address the question of the Tragic from an entirely new perspective for his time and provided the emergence of important further debates both in Literature and Philosophy. There are two main questions which guide the argumentation of this paper: the first one refers to Hölderlin's singular conception of the paradoxes that commonly constitute the Tragic, such as the one between the human and the divine; and the second one, the analysis of the poetic task of Modernity as a possible task to every single poem.
\end{abstract}

KEYWORDS: Hölderlin; Tragic; Oedipus; Poetry.

${ }^{1}$ Doutora em Filosofia e professora da Universidade Estadual do Piauí (UESPI), Parnaíba - PI, Brasil.

COSTA, Solange Aparecida de Campos. Vocação de poeta ou do trágico como tarefa da poesia em Hölderlin. Griot : Revista de Filosofia, Amargosa - BA, v.19, n.1, p.197-214, fevereiro, 2019. 


\section{Introdução}

Friedrich Hölderlin (1770-1843), poeta contemporâneo dos Românticos, escreveu poesias e textos que congregam trabalhos inacabados, projetos e pensamentos aforismáticos, os quais revelam uma compreensão fundamental de seu tempo. A herança poética legada por Hölderlin marcou e continua a marcar a filosofia e a literatura europeia, influenciando o pensamento de grandes filósofos posteriores como e Nietzsche e Heidegger.

Sua produção pode ser dividida em Período de Hipérion (1794 - 1798), Período de Empédocles (1798 -1800) e Períodos dos Grandes Poemas (1808-1806). Neste último, em 1804, traduz e comenta as peças Édipo-rei e Antígona de Sófocles.

Hölderlin ambiciona, tal como seus contemporâneos, criar uma obra especificamente alemã, que represente os anseios de sua época. Um dos grandes temas que perpassa toda obra hölderliniana, desde seus textos de juventude até o período dos grandes poemas, é a definição do trágico, por isso, o poeta recorrerá aos antigos, como uma forma de entender a essência do trágico grego para que consiga definir um caminho para o trágico na modernidade. A ideia não é copiar simplesmente o modelo antigo, mas entender os elementos imprescindíveis da natureza do trágico.

As traduções das tragédias sofoclianas empreendidas por Hölderlin demonstram que, mesmo depois do abandono do projeto de escrever uma tragédia moderna sobre Empédocles, ou em decorrência dele, persiste o desejo do poeta de adentrar o terreno próprio do trágico. No entanto, a recepção desse trabalho de tradução pelos contemporâneos - Voss e mesmo os colegas Schelling e Hegel - não revela cordialidade. Autores contemporâneos a sua época criticaram severamente as traduções, ora pelas mudanças que o poeta faz no texto original de Sófocles, ora pelos erros tipográficos que culminam em numerosas erratas. ${ }^{2}$

Essa atitude negativa será contestada por leituras posteriores, quando autores como Heidegger e Benjamin, entre outros, reabilitam as traduções de Hölderlin, afirmando a importância de sua peculiar interpretação e revitalização dos clássicos gregos. ${ }^{3} \mathrm{O}$ interesse por esses textos de Hölderlin só ganha relevância quando novas teorias da tradução surgem, tornando possível extrapolar o nível de uma suposta preservação do sentido do texto original e observar o conteúdo criativo, a capacidade de tornar viva a linguagem: "Na tradução de um poema, o essencial não é a reconstituição da mensagem, mas a reconstituição do sistema de signos em que está incorporada esta mensagem, da informação estética, não da informação meramente semântica" (CAMPOS, 1999, p. 100).

O objetivo desse artigo não é a análise das traduções hölderlinianas de Sófocles, mas a interpretação dos comentários feitos por Hölderlin a uma das peças traduzidas, as Observações sobre Édipo. Esse texto de Hölderlin, embora de extensão breve, são extremamente densos e contêm uma compreensão profunda e original dos

\footnotetext{
2 Haroldo de Campos, em artigo que analisa o tema da tradução em Hölderlin, retoma as críticas negativas e positivas ao trabalho do poeta alemão e traduz a cena I da Antígona de Hölderlin. Cf. CAMPOS, 1977.

3 Isso aponta, de certa, forma, para o fato de Hölderlin ser um extemporâneo, pois embora se preocupe com discussões de seu período, sua forma de lidar com elas é diversa e reflete uma singularidade no pensamento alemão que só será compreendida e creditada pelos seus pósteros.
} 
elementos que compõem o trágico. ${ }^{4}$

Hölderlin divide as Observações sobre Édipo em três partes:

- A primeira se concentra numa espécie de exame da forma da tragédia, se ocupando de suas leis internas. ${ }^{5}$

- A segunda se ocupa do texto da tragédia, retomando algumas passagens e analisando o texto sofocliano.

- A terceira, mais densa e complexa, apresenta uma compreensão do trágico e de como ele diverge em Édipo-rei e Antígona.

Deter-me-ei neste artigo, especificamente na terceira parte do texto, na qual Hölderlin apresenta o segmento mais duro e intrincado dele, no entanto, paradoxalmente é nesta parte que se encontra também a mais bem acabada investigação hölderliniana sobre a natureza do trágico.

\section{Das contraposições do trágico}

No início da terceira parte das Observações sobre Édipo, Hölderlin afirma que:

A apresentação do trágico repousa, predominantemente, no fato de que o monstruoso, surgido quando deus e homem se pareiam ilimitadamente, quando, na ira, a força da natureza e a interioridade humana se tornam uma só, concebe que o ilimitado de tornar-se um apenas se unifica mediante a separação ilimitada (HÖLDERLIN, 1994, p. 99).

O monstruoso, que pode também ser traduzido como desmesurado, é para o poeta o que fundamenta o trágico, a ele os gregos denominavam deínon ${ }^{6}$, referindo-se ao inabitual, ao extraordinário. O extraordinário que alicerça o trágico é a fraqueza do todo, o outro através do qual o próprio se presentifica, isto é, a necessidade da mediação por um signo. "O extraordinário não pode, portanto, mostrar-se sem o ordinário" (HÖLDERLIN, 1994, p. 116). ${ }^{7}$ Ao tratar da relação entre homem e deus,

\footnotetext{
4 Afirma o comentador Jean Beaufret (2008, p. 26), com exagero, mas percepção acertada: "Seria difícil encontrar, desde que o mundo é mundo, um texto que diga tanto, em tão poucas palavras e com uma densidade tão compacta."

${ }^{5}$ Ainda que Hölderlin analise a forma do trágico, o faz de modo diferente de Aristóteles na Poética. Pode-se dizer que o poeta recorre à terminologia aristotélica para resgatar alguns conceitos como catarse e reviravolta (peripécia); no entanto Aristóteles se baseia numa descrição dos elementos que compõem o trágico enquanto Hölderlin busca compreender o que está além do normativo, qual é a essência mesma do trágico, e como ela comporta consigo uma expressão privilegiada da existência humana.

${ }^{6}$ Rudolf Otto caracteriza o deinós grego como um aspecto do numinoso (sagrado). O autor dedica o capítulo sete do livro $O$ sagrado para tratar desse aspecto do deus e afirma: "A base do seu sentido está no aspecto inquietantemente misterioso [unheimlich] do numinoso. Ao se desdobrarem seus aspectos, ele então se torna dirus e tremendus, terrível e soberbo, descomunal e estranho, esquisito e admirável, assombroso e fascinante, divino, demoníaco e "enérgico"” (OTTO, 2007, p. 79). Otto cita também uma passagem da Antígona de Sófocles no qual o termo é traduzido por assombro. "Muita coisa é ungeheuer/assombrosa. Porém nada é mais ungeheuer/assombroso que o ser humano" (SÓFOCLES apud OTTO, 2007, p.79). Ora, o que está em destaque aqui é a infinitude do sagrado no homem, ou seja, é a potencialidade humana de se equiparar ao divino, mesmo que brevemente e, dessa forma, encontrar a presença do sagrado em si, o universal na singularidade da condição humana. $O$ que Sófocles alude na fala do coro é o extraordinário no ordinário, o deus no homem. Nesse mesmo sentido, o deinós em Hölderlin lembra o espanto que nasce do relacionamento entre deus e homem, e se dá ora pela união, ora pela separação. Tal como na definição de Otto, deinós, ungeheuer, trata desse caráter estranho e inquietante do sagrado ao permitir que no corriqueiro e mundano, se faça um acesso ao extraordinário.

${ }^{7}$ Esse termo faz lembrar também àquela imagem de Heráclito citada por Heidegger em diversos textos quando ele se aquece junto ao fogo e afirma que os deuses também estão ali presentes. É assombroso que os deuses
}

COSTA, Solange Aparecida de Campos. Vocação de poeta ou do trágico como tarefa da poesia em Hölderlin. Griot : Revista de Filosofia, Amargosa - BA, v.19, n.1, p.197-214, fevereiro, 2019. 
a tragédia toca o infinito, mas só pode representá-lo através da finitude da condição humana. Essa possibilidade não revela a infinitude completamente, mas apenas a sugere. A possibilidade de revelação do trágico (baseada na fraqueza da origem, que se deixa apenas entrever) surge da união ilimitada entre homem e deus, isto é, da impetuosa força que unifica a natureza e o âmago do homem. Essa unificação, no entanto, aparece de forma peculiar na tragédia e aí se realiza por meio de uma "separação ilimitada".

A separação ilimitada é a forma que caracteriza o trágico e torna possível entrever a reunião de homem e deus, pela separação. Hölderlin afirma que o trágico deve ser entendido a partir da inusitada união entre deus e homem, que só transparece através de sua própria cesura ${ }^{8}$. A presença desses dois extremos (deus e homem) na tragédia aparece como um dos movimentos vitais para sua realização. A separação de ambos é índice da origem, e na tragédia preserva-se algo da união primigênia que os identificava. A união revela-se na lacuna de sua supressão. Assim, o rompimento do elo entre força da natureza (deus) e o mais profundo do homem é condição necessária para que o trágico aconteça.

Hölderlin cita em seguida, no original grego, embora com pequena variação, uma passagem da Suda9: "Ele foi o escriba da natureza, mergulhando sua pena sensata" (HÖLDERLIN apud ROSENFIELD, 2000, p. 393). O trecho original - "O escriba da natureza que mergulha sua pena em sensatez" - refere-se a Aristóteles, mas Hölderlin altera-o ligeiramente e o emprega para falar de Sófocles, pois pretende atribuir ao poeta trágico o uso dessa "pena sensata" (Cf. ROSENFIELD, 2000, p. 393). O objetivo é lembrar a tarefa do poeta que, ao expor o paradoxo trágico (a união ilimitada pela separação ilimitada), propicia um modo de observar o mundo e suas intrincadas relações. No entanto essa visão não é plena, e nenhuma poderá ser, pois ela (a relação entre homem e deus - união ilimitada pela separação ilimitada) só se deixa ver através de representação. Com a estranha citação da Suda, logo após a definição do trágico, Hölderlin remete à imprescindível tarefa do poeta de ceder aos homens uma visão da dialética do real. A visada do poeta demonstra uma agudeza, uma sensatez equilibrada, capaz de sustentar e mostrar aos outros o trágico da relação deus e homem. Sobre esse mesmo tema, trabalhará Hölderlin (1999, p. 339) no poema "Vocação de Poeta":

\footnotetext{
também moram no ordinário, como o próprio Heráclito (In ANAXIMANDRO, TALES, HERÁCLITO, 1991, p. 58, frag. 119) já afirmara em um de seus fragmentos: "A morada do homem, o extraordinário".

8 A palavra cesura aparece na primeira parte das Observações, com a seguinte explicação de Hölderlin: "A pura palavra, a interrupção antiarrítmica a fim de se encontrar a alternância capaz de arrancar as representações numa tal culminância que o que aparece não é mais a alternância das representações e sim a própria representação" (HÖLDERLIN, 1994, p. 94). Ou seja, A cesura se constitui, como "pura palavra" que transcende os atributos corriqueiros da linguagem e nos transporta (methaphora) para a linguagem em si mesma, essa que separa e une as duas partes da tragédia. A cesura, assim, é pausa, é silêncio. Reúne em si a materialidade (presença em uma cadeia de sílabas) e a imaterialidade (é ausência de som). Ela preserva, portanto essa capacidade de ser uma e dupla, pois ao mesmo tempo remete à palavra como articulação de sons e à sua suspensão, como cisão. Rompe o ritmo, é uma "interrupção anti-rítmica necessária", como diz Hölderlin. Na tradução das Observaç̃̃es para o francês, Naville e Fédier inserem uma nota específica para tratar da cesura e apresentam cinco definições para o termo, que se complementam entre si .Ver NAVILLE; FÉDIER, 2000, pp. $1233-1234$.

${ }^{9}$ Léxico mais abrangente da língua grega surgida em Bizâncio por volta do ano 1000. A Suda (também chamada de Suídas) é um léxico ou, mais exatamente, uma espécie de enciclopédia compilada no século X d.C. por eruditos bizantinos. Seus 30.000 verbetes abordam diversos aspectos da cultura grega (história literatura, língua, religião, costumes, etc.) mas nem todas as suas informações, notadamente as biográficas, são confiáveis.
}

COSTA, Solange Aparecida de Campos. Vocação de poeta ou do trágico como tarefa da poesia em Hölderlin. Griot : Revista de Filosofia, Amargosa - BA, v.19, n.1, p.197-214, fevereiro, 2019. 
Tampouco é bom ser sábio demais. A ele, conhece-o

A gratidão. Mas isso ele não retém fácil, sozinho,

E de bom grado se junta, para que o ajudem

A compreender, o Poeta a outros homens.

O poema aponta que não é bom ser sábio demais (como pretende Édipo, no início da peça; essa ambição seria sua hybris). O poeta tem a justa medida do que é possível saber e revelar.

Tendo em vista essas questões é fácil reconhecer os paradoxos, apontados por Hölderlin na tragédia Édipo-rei. Édipo, ao interpretar infinitamente o oráculo desafia o deus, pois pensa poder ir além dos seus próprios limites, que no início da peça não lhe são claros. Ao transpor sua medida, não se reconhecendo inicialmente em sua condição real, ensaia tornar-se um ilimitado. Mas o ilimitado só se mostra através de uma cisão total, e daí advém o declínio do herói, que é ao mesmo tempo avanço da ação dramática e caminho ao conhecimento. A força da natureza só pode ser vista a partir da quebra realizada pelo herói. Assim sendo, o poder da natureza deixa-se ver pela decadência do protagonista. Ele é o elemento fraco que se pretende igual à força da natureza e que decai e, na sua queda, manifesta intensamente o poder ao qual está submetido, a saber; a natureza, o destino.

O sofrimento do herói é, portanto, imprescindível para a potencialização da natureza. "Para Hölderlin, a tragédia é um sacrifício pelo qual o ser humano ajuda a natureza a aparecer de forma própria, a sair de sua dissimulação original. $\mathrm{O}$ trágico consiste no fato de que o herói deve morrer para prestar um serviço à natureza" (DASTUR, 1994, p. 160). De modo semelhante dirá Szondi (2004, p.34) que: "Hölderlin interpreta a tragédia como sacrifício que o homem oferece à natureza, a fim de levá-la à sua manifestação adequada."

Então, essa tentativa do herói, segundo Hölderlin, de tornar-se um ilimitado - a união que extrapola o limite entre o próprio e o estranho, entre deus e homem só pode existir mediada por uma separação ilimitada. Essa união acontece num impulso, ou seja, a relação de combate entre deus e homem se intensifica na tragédia, até o momento em que um parece se conciliar com o outro. Abre-se um instante, na peça, em que aparecem parelhos, embora seja impossível a fusão completa entre eles, pois que é necessário que cada um preserve seu 'próprio', sua identidade. Esse instante é o "Transport" ${ }^{" 10}$, a peripécia ${ }^{11}$. Ele se concentra em um momento inefável de tomada de consciência, em que, no silêncio, herói e divindade se igualam. Assim,

10 O Transport (transporte) aparece na primeira parte das Observações e se refere a reviravolta que se faz pela quebra do ritmo. Esse elemento mais do que dividir, reúne as duas partes da tragédia, a compondo como um todo orgânico. A escolha do termo Transport mantém clara, sobretudo a dimensão da integração orgânica das partes por meio da peripécia. Em Édipo-rei, a peripécia ocorre quando o protagonista toma conhecimento de si mesmo (como assassino e incestuoso) e assim deixa de ser o que era (glorioso rei de Tebas, herói que livrou a cidade da Esfinge), e o destino se cumpre. A reviravolta acontece pela cesura, que é uma quebra do movimento aparente da tragédia. A introdução desse conceito no texto de Hölderlin se dá por uma analogia com a cesura na métrica em poesia. Sobre transport Rosenfield afirma:. "O critério de beleza depende do vínculo paradoxal entre o inesperado e o verossímil: do surgir de uma e outra ordem, alheia à necessidade das causas materiais, que nos provoca a surpresa de algo totalmente inesperado, mas que, mesmo assim, aparece como verossímil, porque revela contra as expectativas da experiência empírica, umaoutra conexão que não se deduz do conhecimento e do pensamento argumentativos" (ROSENFIELD, 1998, p. 174).

11 Aristóteles na Poética afirma que o reconhecimento é mais belo quando vem acompanhado da reviravolta, peripécia, como acontece na tragédia Édipo-rei. O filósofo considera essa peça de Sófocles como a mais completa justamente porque reúne harmonicamente todos os elementos do trágico. Cf ARISTÓTELES, 1973, Capítulo XI.

COSTA, Solange Aparecida de Campos. Vocação de poeta ou do trágico como tarefa da poesia em Hölderlin. Griot : Revista de Filosofia, Amargosa - BA, v.19, n.1, p.197-214, fevereiro, 2019. 
para que o ágon, a luta, própria do trágico continue existindo, sucede-se a separação deles. A união só é permitida até o momento em que um não se perca no outro, em que ambos resguardem aquela distinção originária que mantém a physis de cada um. Esse paradoxo que constitui o trágico (união-separação entre divino e humano) aparece também no poema "Pão e Vinho" de Hölderlin (1992, p. 59):

O homem apenas algum tempo suporta a plenitude divina.

Depois toda a nossa vida é sonhar com eles [os deuses].

A plenitude divina de que fala o poema é a presença do sagrado, permitida ao homem enquanto se preservam as fronteiras entre ele e deus, protegendo e intensificando o autêntico de cada um. Como a plenitude divina não pode se manter por muito tempo, então, retomando a análise do trágico, o declínio do herói é necessário para reavivar a convivência entre os opostos, tal como ela aparece no poema. Assim, é preciso que Édipo caia em desmedida para que lhe fique exposto o seu limite humano. A união primigênia entre deus e homem só se faz visível quando o rompimento acontece e cada um novamente retoma o seu limite, sua medida.

A dialética da tragédia, que mostra a contraposição entre o divino e o humano, como referido anteriormente, se sustenta pelo ágon, pela luta constante, que é a matriz constitutiva dos próprios diálogos e do caráter dramático da tragédia. Segundo Dastur (1994, p.190): “Para fazer aparecer a própria representação - e não apenas a humana ou a divina em seu intercâmbio -, é preciso a representação global, a figura dinâmica da própria troca, quer dizer, o polemos como tal, é preciso interromper a troca, quebrar o ritmo, o jorro." O ritmo da peça, com o ágon, adquire um movimento mais forte e violento e os discursos assumem esse embate - com os diálogos entre Édipo-Creonte, Édipo-Jocasta, Édipo-pastor.

Depois da cesura ${ }^{12}$, da quebra realizada pela fala de Tirésias, como Hölderlin apontara anteriormente, Édipo age obstinado por descobrir a verdade. Todos os personagens da peça, de alguma forma, tentam dissuadi-lo, mas já é tarde, Édipo já assumira a disputa com o destino, com o divino e consigo mesmo. Por isso, todas as falas parecem, a partir de então, travar batalhas entre si e, simultaneamente, insinuam o crime de Édipo. "Tudo é fala contra fala, superando-se na contraposição" (HÖLDERLIN, 1994, p. 100). A intensidade do diálogo é necessária para a existência da ação trágica, para que ela mantenha o limite tênue entre as duas esferas (Édipo e deus) e instigue o assombro contínuo de cada nova informação. Segundo Peter Szondi, o que se mostra espantoso não é a revelação do assassinato, não é a grandiosidade do crime, mas a maneira como a sucessão entre conhecimento e ignorância se conecta nas falas dos personagens, na relação que alterna aparência e

12 Hölderlin aponta na primeira parte das Observações que pela cesura "Divide-se a sucessão do cálculo e o ritmo, e relacionam-se de tal modo nas suas duas metades que estas aparecem como sendo de igual peso [equilibradas]" (HÖLDERLIN, 2000, p. 386). Apesar de a cesura consistir numa quebra, ela não cinde totalmente a peça em duas partes discrepantes entre si, pois, ao mesmo tempo, que ela separa o fluxo da ação, ela também realiza a união entre esses lados divergentes e harmônicos. Conforme Dastur: "Cesurar, interromper por meio de uma cesura, não significa desarticular, desconjuntar, mas, ao contrário, deixar aparecer no equilíbrio" (DASTUR, 1994, p. 181).

COSTA, Solange Aparecida de Campos. Vocação de poeta ou do trágico como tarefa da poesia em Hölderlin. Griot : Revista de Filosofia, Amargosa - BA, v.19, n.1, p.197-214, fevereiro, 2019. 
realidade de forma tão perfeita, através de uma tensão constante. $O$ que surpreende no trágico é o lento caminhar para a destruição, que se entrevê a cada fala. $O$ paradoxo consiste em que Édipo parece buscar a ruína ao tentar livrar-se dela. Nas palavras de Szondi (2004, p. 89): "Pois não é o aniquilamento que é o trágico, mas o fato de a salvação tornar-se aniquilamento; no fato de o homem sucumbir no caminho que tomou justamente para fugir da ruína."

Szondi aponta também outro aspecto relevante da desmedida humana, a relação que a peça expõe entre salvamento e aniquilamento do herói. Segundo essa análise, Édipo ao desrespeitar os signos do sagrado e buscar exageradamente mais, inicia, ele mesmo, a hybris, pois é o homem que recorre ao oráculo, é Édipo que solicita a intervenção do deus. Nessa perspectiva, demonstra que é o ser humano (Édipo) que busca desvendar o mistério que prende sua ação a divindade, e não o deus que, de forma absoluta e intransigente, conduz a ação humana. Segundo Szondi (2004, p. 89): “Tão importante para a tragédia quanto o poder tácito da divindade sobre o que acontece é a intervenção do deus no fazer humano, solicitada pelo próprio homem e expressa em palavras através do oráculo". É o homem, portanto que, de forma desmedida, requisita um conhecimento absoluto do sagrado.

Édipo busca no oráculo adquirir um saber para além do que lhe compete. Laio foi o primeiro a consultar o oráculo e recorrer à mediação divina, Édipo lhe dá continuidade, ao buscar fugir dela. Buscando escapar, ele torna ainda mais premente o seu destino.

No texto de Hölderlin, ainda tratando do constante ágon presente na peça Édipo-rei ("Tudo é fala contra fala"), o autor comenta o vigor e a intensidade que as falas e as cenas apresentam. Os diálogos cortantes, entre Édipo e Creonte, Édipo e Jocasta, Édipo e o pastor, vão sucedendo um ao outro numa tensão progressiva até a decadência absoluta do herói. Os próprios comentários de Hölderlin se tornam como que imbuídos desse ritmo alucinante que a peça ganha. Dirá Hölderlin (1994, p. 100) sobre as cenas que antecedem a catástrofe:

Tudo é fala contra fala, superando-se na contraposição [...] Nas cenas, as
formas que festejam o pavor, o drama, como o de um processo de heresia,
como a língua para um mundo onde, sob a peste, a loucura e um espírito
vaticinador, a toda parte exacerbado, onde num tempo de ócio, deus e
homem se compartilham na forma da infidelidade, essa que tudo pode
esquecer, pois a infidelidade divina é o que há de melhor para se preservar
a fím de que o transcurso do mundo não possua nenhuma lacuna $e$ a
memória do celeste não escape.

Nessa passagem, Hölderlin se refere a um tempo de ócio, onde vige a inoperância do divino, onde aquela presença efetiva do deus não mais existe. A presença do deus surge, na peça, através do oráculo, que é referido em diversos trechos. $O$ deus não aparece de forma efetiva, por meio de um personagem, mas através de sua dissimulação, de elementos como: o enigma oracular, os discursos de Tirésias, as imprecações lembradas pelas falas dos personagens e a própria existência da peste que assola a cidade (alguns referidos por Hölderlin na citação acima).

Nesse sentido, pode-se dizer que a presença do deus está mais na memória na lembrança da divindade pela qual se clama e que se requer durante a peça - do que num personagem determinado. Nessa peça de Sófocles, percebe-se que os deuses

COSTA, Solange Aparecida de Campos. Vocação de poeta ou do trágico como tarefa da poesia em Hölderlin. Griot : Revista de Filosofia, Amargosa - BA, v.19, n.1, p.197-214, fevereiro, 2019. 
não agem de maneira objetiva, mas se revelam nos signos do sagrado que aparecem de forma recorrente na peça: como o oráculo ou as falas de Tirésias. Assim, é possível compreender a citação de Hölderlin sobre esse tempo de ócio: os deuses não intervêm diretamente na trama, sua presença e força só é percebida pela ausência (pelos signos), pela ociosidade, pela miséria que é imposta pela distância do divino.

\section{O afastamento categórico do deus}

Segundo as Observações sobre Édipo, o trágico aparece na peça também, de modo singular, a partir do "afastamento categórico do deus" (1994, p. 100), elemento que não aparece em outras tragédias. Ao analisar a interpretação de Hölderlin da peça Édipo-rei, dirá Beaufret (2008, p. 22): "Assim, para Hölderlin, o trágico de Sófocles é o documento essencial desse afastamento categórico do divino [grifo meu], que é, a seus olhos, a própria essência da tragédia, e que nem Ésquilo nem Eurípides conseguiram objetivar tão plenamente." Ou seja, enquanto em Édipo-rei o herói se descobre apartado da presença divina e a ele se impõe a tarefa de assumi-la até o fim, condenando-se ao exílio, nas outras tragédias - de Ésquilo e Eurípides - ao declínio do herói sucede geralmente a morte, e o deus é que estabelece sua sentença.

$\mathrm{O}$ afastamento categórico ${ }^{13}$ aparece nos textos hölderlianos sob a influência de Kant, embora Hölderlin o utilize para tratar do trágico que se apresenta sob a forma da retirada do deus. Pode-se entender, então, que quando aparece a noção de infidelidade divina, ela preserva algo também daquilo que Kant denominava Incondicionado, ou seja, as coisas em si mesmas, o aspecto não-conhecido do nôumeno. A esse respeito dirá Lacoue-Labarthe (1998, p.38, tradução minha): "O afastamento do divino não significa a ausência ou desaparecimento de Deus. Ele é categórico, no sentido kantiano, incondicionado, ele designa tudo, a presentificação da Lei. O afastamento é a Lei". A lei é a imposição do destino, é a condição originária, à qual estamos submetidos desde sempre e a qual não podemos completamente conhecer.

No poema "Pão e Vinho", já mencionado anteriormente, importante para compreender a noção de sagrado para Hölderlin, o poeta também faz referência ao "tempo de indigência", a uma forma de perda do sagrado, um momento de ausência do deus, tal como o referido nas Observações sobre Édipo. O poema comenta que nesse tempo de indigência os poetas seriam como deuses, por assumir sua tarefa num tempo em que tudo está fora do lugar. Dirá Hölderlin (1992, p. 59): ${ }^{14}$

Nem sei perseverar assim, nem que fazer entretanto,

\footnotetext{
${ }^{13}$ Sobre o afastamento categórico do deus, Roberto Machado e Pedro Süsskind inserem uma nota explicativa na tradução que fazem do texto hölderliniano, na qual afirmam: "Umkenhren tem o sentido de voltar, retornar, fazer a volta, regressar, inverter, dar as costas, virar o rosto. Optamos, algumas vezes pelos termos "afastar-se" para o verbo umkehren e "afastamento" para o substantivo Umkehr, mas outra vezes pelo termo "retorno" e "retornar" quando o sentido o exigia. Lacoue- Labarthe assinala que, no alemão da época, essas palavras remetem à Revolução Francesa e têm o sentido geral de subversão, revolta." (MACHADO; SÜSSKIND, 2008, p. 79). Neste artigo, embora adotemos preferencialmente a tradução de Márcia de Sá Cavalcante para o termo, optamos tal como os tradutores acima explicitam, por traduzi-lo de diferentes modos, conforme a necessidade específica do contexto textual.

${ }^{14}$ Heidegger recupera essa passagem e escreve o texto Porquê poeta? em que analisa uma época sem deus, sem fundamento [Abgrund = abismo, sinônimo de "não fundamento"]. Ver Heidegger (1951).
}

COSTA, Solange Aparecida de Campos. Vocação de poeta ou do trágico como tarefa da poesia em Hölderlin. Griot : Revista de Filosofia, Amargosa - BA, v.19, n.1, p.197-214, fevereiro, 2019. 
Nem sei que dizer, pois para que servem os poetas em tempos de indigência?

Mas eles são, dizes, como sacerdotes santos do deus do vinho.

Que em noite santa vagueavam de terra em terra.

O poema comenta sobre esse tempo em que tudo está fora do lugar porque deus se afastou dos homens, ou seja, ocorreu o que Hölderlin chama de retorno categórico do divino. Os deuses antes eram muito presentes no cotidiano grego, através dos ritos ou mesmo interferindo nas ações humanas, como atestam as peças anteriores, de Ésquilo, por exemplo. Agora, Homero, com sua sobriedade ocidental de Juno $^{15}$, havia introduzido no mundo grego a poesia e a arte com esse sentido que Hölderlin definirá séculos mais tarde: enquanto elemento estranho, em contraposição ao pátrio. E como consequência os deuses se afastaram do homem. É esse abandono de deus, tal como apontado nas Observações, que Édipo vive. Hölderlin (1992, p. 59) define no poema esse momento de ocultação dos deuses como algo sofrido, um luto, para o homem:

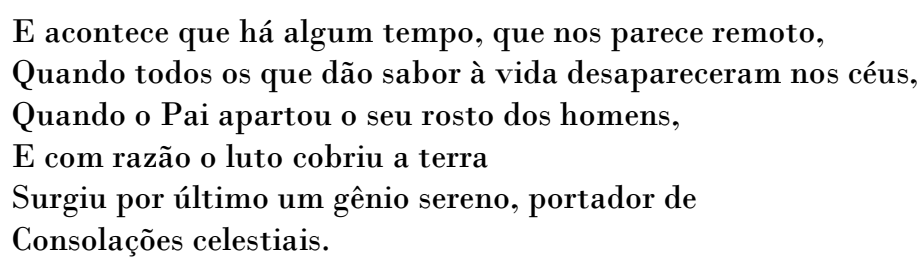

No entanto, nos versos seguintes Hölderlin comenta sobre o surgimento de um gênio sereno. Esse "gênio sereno" é o poeta que preserva algo daquele vínculo original e reestabelece a paz pela palavra; a poesia retira, nesse sentido, a angústia do homem causada pelo afastamento de deus. $O$ poeta seria, então, uma das causas possíveis de uma nova reedificação humana perante a situação de ausência dos deuses. No trecho abaixo do poema, Hölderlin (1992, p.61) caracteriza a tarefa do poeta nesse tempo de dificuldade:

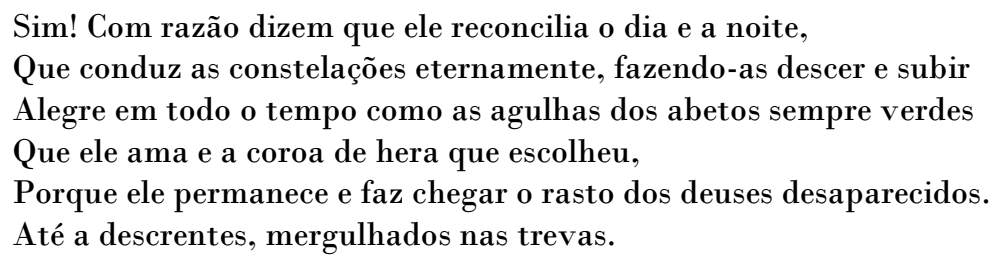

O mesmo poema ainda afirma que se preserva alguma gratidão que os homens possuem em relação ao divino: "Mas em silêncio vive alguma gratidão ainda." (id., p. 61) Essa gratidão que o homem possui, tal como a poesia, é que sustenta o nãoesquecimento, mantém o elo remanescente daquela fusão originária, da unidade de onde ambos procedemos (deus e homem) e que carregamos conosco. Segundo Hölderlin, essa unidade - já referida anteriormente, em uma de suas formas, pela poesia - quando emerge nos salva de um total obscurecimento. Por isso precisamos

15 Segundo Antônio Cícero (2005, p. 249): “A sobriedade representa uma primeira separação entre sujeito e objeto, ser humano e natureza."

COSTA, Solange Aparecida de Campos. Vocação de poeta ou do trágico como tarefa da poesia em Hölderlin. Griot : Revista de Filosofia, Amargosa - BA, v.19, n.1, p.197-214, fevereiro, 2019. 
mantê-la, a fim de não perdermos nossa identidade, que é um modo de tentar resguardar viva a memória do deus.

Então, para não nos esquecermos da união ilimitada, buscamos seu sentido na realidade objetiva. Fazemos que as coisas existentes nos tragam a lembrança do nosso pátrio, do tempo em que o divino se revelava. E, assim, com olhos atentos, podemos ver na realidade, que ora emerge, resquícios do chão que lhe deu origem. Na elegia, o próprio pão e o vinho ${ }^{16}$, tal como a poesia, aparecem como frutos dessa tentativa de proteger o vínculo com o sagrado.

A Modernidade se revela também como um tempo de ócio, ou como diz Hölderlin (1992, p. 59), um "tempo de indigência" (dürfitiger Zeit), Pois perdemos os deuses. Segundo Hölderlin (1992, p. 53) vivemos só, estamos em "hora de indecisão" (der zaudernden Weile). Os deuses não estão tão próximos como estavam na Grécia de Ésquilo. Entre os helenos, antes da sobriedade de Homero, a presença do divino se revelava em tudo: nos templos que se espalhavam pelas cidades, nos festivais, nos rituais de sacrifícios, estes entre outros exemplos. Em todas as atividades da cidade os deuses sempre eram lembrados. Mas agora, essa presença não mais vigora, o nosso pátrio não é mais o fogo do céu, a força do sagrado, mas o cálculo e a precisão da palavra, o domínio de formas e conceitos, a razão.

Ao afastamento do deus seguiu-se, para o homem, um tempo de pesar e hesitação. Pois que o homem estava acostumado com a presença sempre efetiva do deus e, agora, tinha que compreender sua relação com o divino sob um novo aspecto: o do afastamento. Essa perda trouxe, portanto, insegurança e para que não sucumbíssemos à dor da separação foi preciso manter viva a lembrança do divino. É disso que trata a elegia, também quando diz:

\footnotetext{
Nos conceda a palavra fluente que, como amantes,

Permaneça em vigília, a taça mais repleta e a vida mais audaz,

E também sagrada a memória para que acordados fiquemos enquanto a noite dura (HÖLDERLIN, 1992, p. 53).
}

Para nos mantermos acordados, isto é, para sustentarmos o vigor da existência, há que se preservar a memória dos celestes, tal como fazem os poetas em tempo de indigência, fazendo ver nisto que é o nosso pátrio - que devemos conquistar (a palavra fluente) - uma forma da presença de deus (deus enquanto fundamento daquela união originária da realidade, do pátrio). A tarefa do homem, agora, é entender o divino através do seu afastamento. Ou tal como Hölderlin também fala da nas Observações sobre Édipo (cf. Hölderlin, 1994, p. 100), a necessidade de preservar a memória celeste através da infidelidade divina.

Na Modernidade, apartados da presença de deus, a lembrança do elemento originário, compartilhado por todos, é o que garante que não sejamos dissolvidos pelas necessidades vazias da vida mundana. Como alcançar esse elemento? Pode-se atingi-lo pelo equilíbrio em assumir plenamente a nossa existência enquanto tal, sem excessos ou faltas. Os gregos conseguiram apreendê-lo de modo exemplar. $\mathrm{O}$ destino do homem é ser homem e assumir essa tarefa sem recorrer a subterfúgios ou

16 "Por isso junto a eles [o pão e o vinho] recordamos os deuses" (HÖLDERLIN, 1992, p. 61). 
abandoná-la pela inércia. Dessa forma, poderá ultrapassar a sua indigência, a falta do divino, tal como Hölderlin (2001, p. 168-169) define no texto "Sobre a religião":

O homem também alça-se além da carência, já que pode recordar seu destino, e que pode ser grato pela vida a ponto de sentir com mais largueza o elo mais amplo com o elemento onde ele próprio se desloca; já que ele se alça para além da necessidade graças à eficácia e às experiências que isso traz consigo. [...] Digo: aquele elo mais infinito, ultrapassando a necessidade, aquele destino mais elevado que o homem experimenta em seu elemento, ele o experiencia mais infinitamente, satisfazendo-se mais infinitamente.

O homem só toca a infinitude na medida em que percebe a contingência de ser finito e pode, portanto, vislumbrar o fundo originário de si mesmo e do real. ${ }^{17} \mathrm{Não}$ vê a realidade enquanto fato, mas o que doa e sustenta sua vigência da realidade. Escreve Hölderlin (1994, p. 66) no texto Sobre a religião:

Se o homem souber tocar oportunamente, descobrirá, em cada uma das esferas que lhe são próprias, uma vida mais elevada, maior do que a pautada pela necessidade, ou seja, uma satisfação mais infinita, maior do que a satisfação das necessidades. Da mesma maneira que toda satisfação, essa satisfação mais infinita é também uma pausa momentânea da vida real.

O homem ultrapassa o nível das necessidades corriqueiras e passa a se aproximar do elemento que lhe deu origem, como se escutasse o nascer de sua própria natureza.

No entanto, como vimos, não é apenas pelo pensamento que o homem esgota plenamente o elo com o divino, o rigor intelectual não explica a divindade, que pode ser pressentida através de suas próprias leis. Essas leis não são as jurídicas ou formais, Hölderlin cita o exemplo de Antígona que clama à lei divina para enterrar o irmão. Ao invocar a lei divina, Antígona recorre ao elemento primevo que mantém a união familiar antes mesmo das leis civis e familiares existirem. A lei divina precede o surgimento das regras formais e de conveniências: ela estabelece o modo de existir do homem em harmonia com todos os outros elementos da natureza. Trata, portanto, do elemento universal e não da existência particular dos indivíduos. Nas palavras de Hölderlin, nos versos finais do hino tardio "Patmos" temos:

\footnotetext{
17 A relevância dessa idéia para Hölderlin revela-se também na epígrafe do romance Hipérion: "Non coerceri maximo, contineri minimo, divinum est." Trata-se da inscrição tumular de Inácio de Loyola, fundador da ordem dos Jesuítas, e significa: "Divino é não estar limitado pelo que há de maior e mesmo assim estar cingido pelo que há de menor." A referência de Hölderlin ao epitáfio de Inácio de Loyola aparece anteriormente também num “esboço de Hipérion”, publicado em 1794, na Revista Thalia de Schiller (esse texto recebe o nome, nas obras de Hölderlin, de Fragmento Thalia). Nesse artigo Hölderlin comenta que o homem possui dois estados ideais: o de extrema simplicidade e de extrema cultura e ambiciona constantemente alcançá-los. Segundo Hölderlin (2004, p. 113) a frase do epitáfio "pode assinalar a perigosa tendência do ser humano de tudo querer e a tudo subjugar como o mais alto e mais belo estágio que ele possa atingir". Segundo as notas de Philippe Jaccottet nas obras completas de Hölderlin em francês, essa epígrafe é apenas um pequeno extrato de um longo epitáfio ao padre jesuíta. Jaccotet (in HÖLDERLIN, 2004, p. 1153) afirma que "Parece que Hölderlin interpretou essa frase como a oposição de duas atitudes humanas possíveis: conquista e sabedoria, expansão e concentração."
}

COSTA, Solange Aparecida de Campos. Vocação de poeta ou do trágico como tarefa da poesia em Hölderlin. Griot : Revista de Filosofia, Amargosa - BA, v.19, n.1, p.197-214, fevereiro, 2019. 


\author{
... mas o pai ama, \\ ele que vige sobre todos, \\ muitíssimo, que seja cuidada \\ a letra firme, e o consistente bem \\ interpretado. Segue-o o canto alemão.
}

A letra firme se constitui como a lei divina que permite ao homem relacionarse com o deus. Ao interpretá-la, o poema coloca o homem frente à força originária da natureza. Pode-se dizer, então, que existe uma tensão entre a letra firme, a palavra do deus, e o que subsiste, a interpretação do divino. $O$ homem deve cuidar dessa relação e mantê-la sempre pulsante, para que a palavra do deus não se perca e, como afirma Hölderlin (1994, p. 100) nas Observações: “a memória do celeste não se acabe".

O canto alemão almejado é o espaço polissêmico da poesia, fruto da liberdade criadora, local uno de encontro entre o pátrio e o estrangeiro e, portanto, o elemento que pode preservar essa relação de forma mais plena. No entanto, ao mesmo tempo em que a liberdade da criação oferece ao poeta uma amplitude de possibilidades para sustentar a letra firme, mantém-no em um lugar intermediário entre a palavra do deus e a existência humana. Cabe ao poeta conquistar o "fogo dos céus" 18 , isto é, seu pátrio, sua natureza e, dessa forma, ser fiel à letra firme.

O "fogo dos céus" é aquilo que Hölderlin havia definido como elemento essencial que liga o humano ao divino e mantém a harmonia entre eles. $O$ pátrio é o solo nativo, o lugar de pertença de um povo, o espaço que não pode ser medido por área territorial, mas garante a singularidade de um homem ou um grupo, porque os identifica e legitima sua existência. A tarefa da poesia alemã é árdua porque se conserva no "entrelugar", na fugacidade do espaço que se transforma constantemente entre o homem e a palavra do deus.

\title{
Do papel do herói e do poeta, a partir da dupla infidelidade
}

Dos temas tratados até aqui se pode inferir que Hölderlin recebe uma forte influência das discussões de sua época (a diferença entre poética antiga e moderna, por exemplo), mas a sobrepuja de modo a buscar um caráter original que transcenda os modelos pré-concebidos de seus contemporâneos. Hölderlin é, sem dúvida, um homem de seu tempo, sente as mudanças causadas pela Revolução Francesa, pelas discussões políticas, pela necessidade de criar uma escrita alemã frente aos padrões estrangeiros; no entanto, esses são apenas os elementos que circundam e instigam seu trabalho em princípio. Pois só quando adentra o âmbito da arte, quando passa a sentir a liberdade criadora da própria poesia é que sua ação se efetiva e sua argumentação se desloca para o lugar anterior, existencial, que propicia toda e qualquer argumentação sobre sua época.

Segundo as Observações sobre Édipo, afinal, após o afastamento do divino, deus e homem se relacionam pela infidelidade. O deus é infiel porque se afasta do

\footnotetext{
${ }^{18}$ Esse termo "fogo dos céus" aparece na carta que Hölderlin escreve ao amigo Böhlendorf, na qual apresenta a diferença entre os gregos e os modernos: "Nada se aprende com mais dificuldade que o livre emprego do [elemento] nacional. E creio que a clareza da representação é tão originalmente natural em nós quanto nos gregos foi o fogo dos céus. Por isso, justamente, cabe superar estes últimos, os gregos, antes na passionalidade bela [schön] (...) que naquela lucidez [presença de espírito] e aptidão de representar homéricos."(HÖLDERLIN, 1994, p. 132).
}

COSTA, Solange Aparecida de Campos. Vocação de poeta ou do trágico como tarefa da poesia em Hölderlin. Griot : Revista de Filosofia, Amargosa - BA, v.19, n.1, p.197-214, fevereiro, 2019. 
homem; não que ele deixe de existir, sua força continua vigorando, mas isso se dá sob uma nova forma, a do seu afastamento, na voz do oráculo, por exemplo. $\mathrm{O}$ divino age agora através da lembrança. Ao homem cabe a tarefa de aceitar o afastamento do deus, como única forma possível de acesso ao divino devendo, então, cuidar da lembrança do sagrado, preservá-la. Pode-se entender a superação da infidelidade divina (a retirada do deus), no texto de Hölderlin, como uma empreitada que cabe ao homem assumir; só tornando sua essa tarefa é que o homem pode preservar a lembrança do divino. Por isso Édipo aparece, nota Jean Beaufret, como átheos ${ }^{19}$ : Édipo é o sem deus, ele é o herói abandonado pelo divino, cabe a ele agora assumir a sua existência a partir da falta do deus. Édipo não é morto nem condenado a agonizar no cume de um rochedo como Prometeu fora, o deus não lhe impõe nenhuma pena, isto é, ele não recebe nenhum castigo como uma sentença a ser cumprida. O que Édipo sofre é o abandono do deus e o que ele pode fazer é apenas assumir a sina de tal solidão. Nas Observações Hölderlin dá indicações de que, ao fazer seu tal designo, o do afastamento do deus, Édipo pode viver, a partir de então, para realizar essa tarefa. $O$ destino de Édipo se configura, desse modo, em tomar sobre si a infidelidade divina. Beaufret (2008, p. 24) expõe a seguinte pergunta sobre Édipo: "Qual é então seu destino? Aprender a assumir, ou seja, a fazer seu tal abandono."

À infidelidade divina segue a infidelidade humana. O homem é, como afirma Hölderlin (1994, p. 100) nas Observações, um traidor: "Nesse momento, o homem esquece de si e de deus, convertendo-se, embora de modo sagrado, como um traidor. - Nos limites mais extremos da dor, nada mais resta senão as condições de tempo e do espaço".

Desse modo, segundo Hölderlin, Édipo - a partir da catástrofe, do reconhecimento de si como causador da morte de Laio e do incesto inconscientemente praticado - cede ao esquecimento de si e de deus, esquecimento também necessário para dar vazão a uma relação única com o divino. A partir da infidelidade torna-se acessível ao homem uma memória não mais presa ao antes e depois, a memória é agora aquela que permite a existência do tempo enquanto tal é justamente aquilo que une o antes ao depois. Mas esse esquecimento não se concede mais a Édipo. E novamente temos o paradoxo: até então afirmávamos que era preciso manter a memória do divino para conseguir assumir a infidelidade do deus, isto é, seu afastamento. Agora o esquecimento nos aparece como necessário, como imprescindível para poder preservar essa memória.

Ora, esse esquecimento não é contrário à lembrança do divino, ele consiste em olvidar a si mesmo e a deus como formas pré-concebidas, como conceitos já fixados no mundo, para entendê-los desde aquele âmago originário, desde o movimento que permitiu que as formas externas de seu aparecimento fossem exequíveis. Esse momento que não é possível quantificar - o momento da dupla infidelidade, do duplo esquecimento, do nascimento de uma nova memória - deixa transparecer a força da natureza que doa ao homem seu destino. "Semelhante esquecimento é, portanto, para o homem, portanto, o nascimento de uma memória de si mesmo mais profunda do que tudo que pensava ser até então." (BEAUFRET, 2008, p. 28).

19 “Não ateu, mas desertado tanto quanto possível pelo deus que dele se separa e se afasta." (BEAUFRET, 2008, p. 23)

COSTA, Solange Aparecida de Campos. Vocação de poeta ou do trágico como tarefa da poesia em Hölderlin. Griot : Revista de Filosofia, Amargosa - BA, v.19, n.1, p.197-214, fevereiro, 2019. 
Esse duplo esquecimento, que aparece no texto de Hölderlin, abre ao homem um instante em que ele pode vislumbrar inteiramente a si mesmo (o que o caracteriza como tal, o seu elemento único, sua diferenciação que não permite que ele seja outra coisa). $O$ anseio de figuração desse momento é a matriz formal da tragédia. $O$ herói trágico - nesse caso em particular: Édipo - é o exemplo de como o homem pode esquecer de si enquanto homem determinado (com certas virtudes, vícios, trejeitos próprios) e olvidar suas características externas para adentrar na visão do que possibilita nele tais características, enquanto possibilidade para tal homem singular. Segundo Rosenfield (2000, p. 394):

O herói desvia-se dos objetos sensíveis ou cognoscíveis de seu mundo (da 'terra') para precipitar-se no ilimitado do possível. $O$ esquecimento de si e de deus aparece aqui como o abandono da posição mediana (do 'lugar' propriamente humano), situada entre o pensamento que reconhece as regras do conhecimento e um saber de outra ordem.

Através desse esquecimento surge no herói a lembrança da origem, do vigor próprio que lhe permite existir. Essa memória se funda no seu pátrio, no solo nativo que lhe deu origem. Esse é o retorno categórico. É o momento em que o homem esquece de si como indivíduo e lança o olhar sobre si como possibilidade, como base que propiciou o nascimento do indivíduo. "Mas a arte só é plenamente arte por aquilo Hölderlin nomeia insolitamente de vaterländische Umkehr [retorno à terra pátria]:o retorno, a volta, que remonta até a própria essência do nativo" (BEAUFRET, 2008, p. 11).

Hölderlin define o homem como traidor nas Observações sobre Édipo porque para se lançar nessa tarefa tem de esquecer de si e de deus como formas já conceituadas no mundo. Ele é traidor, nessa esfera do trágico, porque consegue plenamente realizar uma ligação com a infidelidade divina. Consegue perceber em si mesmo a memória do antigo, a memória de si enquanto condição de possibilidade que antecede o indivíduo, e a memória de deus não como presença perdida que pode ser reconquistada, mas como tempo, aquilo que permite ao homem (no seu afastamento) o encontro de si mesmo, do pátrio, da natureza.

Deus, no retorno categórico em que se dá o duplo esquecimento, aparece como tempo. Ele é tempo na medida em que se constitui como anterior ao sentido epocal ou a qualquer conceito cristalizado de medição da existência. Dirá Hölderlin (1994, p. 100) mais adiante nas Observações que: "Nesses limites, o homem esquece de si porque está inteiramente lançado ao momento e a deus. Porque deus nada mais é que tempo." Deus, nesse sentido é tempo como pura condição, como tão-somente possibilidade. Por isso, pode-se afirmar desse modo que o tempo é vazio ( pois nada mais lhe resta de referência senão o nada, o que ainda não aconteceu; mas é ele, por outro lado, que torna qualquer acontecimento possível. Só assim, num estado em que as categorias de espaço e tempo ainda não foram definidas por alguma situação específica, torna-se possível a dupla infidelidade, pois o deus não tem como se revelar aos homens através de um signo, nem o homem pode se agarrar a sacrifícios para atingir o divino. Tudo isso foi absolvido pelo elemento que dá existência a qualquer relação. Dirá Beda Allemann (1959, p. 238) que: “A forma

COSTA, Solange Aparecida de Campos. Vocação de poeta ou do trágico como tarefa da poesia em Hölderlin. Griot : Revista de Filosofia, Amargosa - BA, v.19, n.1, p.197-214, fevereiro, 2019. 
como o Deus pode ser infiel aos homens é ser/estar manifesto como o céu livre e vazio. Ausente e incompreensível, o Deus não se dispõe mais através de signos."

Assim, pode-se entender por que há necessidade da transformação de Édipo que, antes, renega várias vezes o deus ao duvidar do oráculo, e depois se torna pleno, pela dupla infidelidade, ao ter de assumir o seu destino. Édipo, governante de Tebas, no início da tragédia não ouve nada nem a ninguém, nem a voz do deus o toca, pois ele persiste em conhecer mais do que lhe compete. Não é fulminado como Semele (personagem d mitologia que tem uma morte imediata), mas após conseguir contemplar a si mesmo, a sua origem, ele mesmo se condena a vagar na errância. A traição de Édipo fora lançar o olhar sobre sua identidade, assumindo depois o abandono do deus como fruto do que se lhe apresentara nessa visão, na qual deus e homem aparecem na sua configuração originária.

Por isso, diferente dos desfechos de outras peças, Édipo tem de tornar-se cego, pois não pode suportar a pura visão da origem, o elemento unificador da natureza, a unidade que antecede a multiplicidade. Tem de prestar um sacrifício, tem de perder algo de humano ${ }^{20}$. Nessa busca desenfreada por saber demais, ultrapassando o limite que sua condição humana lhe impõe (mesmo tendo sido advertido por Tirésias e por Jocasta), Édipo lança-se sem saber ao 'lugar' onde tempo e espaço não vigoram. Nesse momento é que ocorre a união ilimitada através da separação ilimitada de deus e homem, apontada por Hölderlin; somente nesse extremo é que o homem se dá conta de sua própria finitude. Dirá Lacoue-Labarthe (1998, p. 37, tradução minha) que: "Resta [nas 'Observações sobre Édipo'] que o momento trágico consiste na prova improvável, por definição, do transcendental nele mesmo, isto é, da finitude como tal."

Recordar-se-á novamente as palavras de Hölderlin (1994, p. 100):

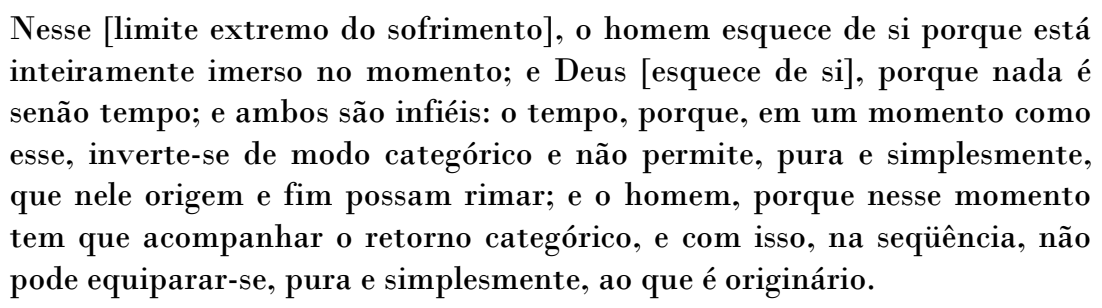

Segundo a análise do poeta Édipo não pode mais se comparar ao Édipo do início, ele já não é mais o mesmo. O salvador de Tebas se revela o responsável pela desgraça da cidade, de sua família e de si mesmo. De acordo com a citação acima, o tempo é categórico porque não há nada além dele, não existe bondade ou maldade em sua imposição, há apenas a necessidade da realização do destino. Para que se cumpra a palavra do deus, ainda que pelo seu afastamento. Mas Édipo não é uma marionete nas mãos do destino, ele age o tempo todo, tanto que comete a desmedida. Édipo não ouve o deus, busca fugir de suas palavras, busca interpretá-las a seu

${ }^{20}$ Esse movimento da perda fisiológica da visão para uma capacidade de olhar mais aprofundado, tal como se aplica na tarefa do pensamento poético ou filosófico, lembra algumas referências que aparecem nos diálogos platônicos: "Em verdade, a visão do pensamento começa a ver com acuidade, quando a dos olhos tende a perder a força" (Platão. O Banquete, 219a). Na tradição cristã, há entre outros o exemplo da conversão de Saulo, cf. At 9 , $1-19$.

COSTA, Solange Aparecida de Campos. Vocação de poeta ou do trágico como tarefa da poesia em Hölderlin. Griot : Revista de Filosofia, Amargosa - BA, v.19, n.1, p.197-214, fevereiro, 2019. 
modo. $\mathrm{O}$ deus, presente nas falas do oráculo e de Tirésias, adverte-o insistentemente para que preserve a memória, para que resguarde a presença divina.

Se Édipo compreendesse que a fidelidade à cidade consiste em respeitar o deus, talvez houvesse outro desfecho na peça, no entanto, a tragédia não aconteceria. Mas Édipo, por ser um herói trágico, tem de sucumbir, tem de perceber apenas tarde demais que se afastara do deus; e vice-versa, que ele não pode mais governar a cidade, que nunca, na verdade, foi legítimo o seu reinado. Segundo Dastur (1994, p. 186): "O imperativo só se torna categórico quando não tem mais fundamento teológico, quando o deus se retira, na época em que o homem está em luto da divindade." Por isso pode-se dizer que o tempo é categórico, porque não há saída, não há escapatória e, pior, não há mais divindade a que se agarrar. Édipo fica defronte a si mesmo, ao sem-sentido da existência, e sua única possibilidade é assumir essa tarefa de ser sem-deus e, ainda assim, continuar querendo existir. No poema "Vocação de Poeta"21, escrito em 1800, Hölderlin pressente e tematiza a distância de deus tal como o que aparecerá mais tarde nas Observações. Dirá Hölderlin (1999, p. 339) no final do poema:

Mas sem medo fica, quando é preciso, o homem
Sozinho ante Deus, a candura o protege,
E não são precisas armas nem manhas.
Até que a falta de Deus o venha ajudar.

Essa relação de afastamento do sagrado que aparece no poema, mostra-se nas Observações como o elemento trágico mais intenso da peça Édipo-rei. Assim, a tragédia de Sófocles trata, na análise de Hölderlin, da perda do sagrado, e como o homem (o herói - Édipo) se situa frente a essa situação. Segundo Machado (2006, p. 160):

\begin{abstract}
Édipo é o herói que é coagido a se manter à distância dos deuses e dos homens, que deve separar essa dupla separação, guardar pura essa distância sem preenchê-la com vãs consolações, manter como que um entre-dois, lugar vazio aberto pela dupla aversão, a dupla infidelidade dos deuses e dos homens, e que ele deve guardar puro e vazio, a fim de que seja assegurada a distinção das esferas, distinção que a partir de então é nossa tarefa.
\end{abstract}

No entanto, o exame que Hölderlin faz da peça sofocliana não se restringe ao estudo do trágico ao modo grego, mas, sobretudo, ao afastamento do divino que também é inerente à poética alemã de seu tempo. Hölderlin trata portanto, via Sófocles, de como pode e deve o poeta moderno se portar frente ao afastamento do divino. Desse modo, o destino de Édipo, segundo Hölderlin, não é apenas o destino do herói clássico, mas uma representação que permite pensar o trágico na modernidade ${ }^{22}$. Daí a opção de Hölderlin, em seu percurso, por uma tradução do texto antigo, após o abandono do projeto de Empédocles em estado inacabado.

${ }^{21}$ Esse poema é escrito no mesmo ano da elegia "Pão e Vinho", é o chamado "Período dos grandes Poemas" que abrange os anos de 1800 a 1806. As Observações também são realizadas nessa época, sendo publicadas no ano de 1804 .

${ }^{22}$ Segundo Blanchot (1987, p. 275): "Hoje o poeta não pode mais colocar-se entre os deuses e os homens, como intermediário deles, mas cumpre-lhe manter-se entre a dupla infidelidade, manter-se na intersecção desse duplo

COSTA, Solange Aparecida de Campos. Vocação de poeta ou do trágico como tarefa da poesia em Hölderlin. Griot : Revista de Filosofia, Amargosa - BA, v.19, n.1, p.197-214, fevereiro, 2019. 
Esse sentido aparece também no poema "Como em dia santo", da mesma época das Observações. Hölderlin (1999, p. 373) termina com esses versos o poema que trata da difícil tarefa que se impõe ao poeta na modernidade:

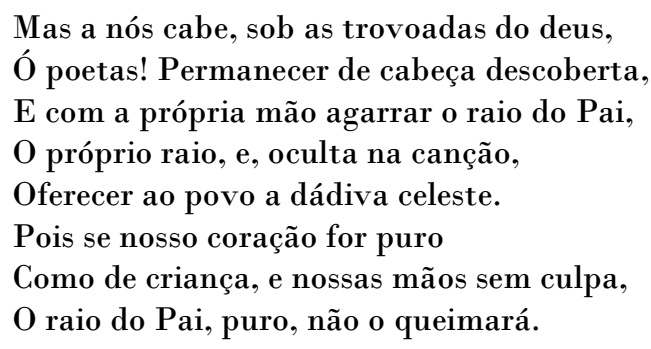

A questão que se impõe a Hölderlin nas Observações é como transformar a solidão, a nostalgia e a fraqueza causada pela ausência divina em nova potência de vida e forma. Hölderlin afirmará que cabe ao poeta assumir esse vazio, ele pode através de instrumentos específicos (como a tragédia), mostrar ao homem que ainda subsiste sua força própria: Ao poeta cabe, e não, com a própria mão, agarrar o raio do Pai, o próprio raio, e, oculta na canção, oferecer ao povo a dádiva celeste.

retorno divino, humano, duplo e recíproco, movimento pelo qual se abre um hiato, um vazio que deve constituir doravante a relação essencial dos dois mundos." 


\section{Referências}

ALLEMAN, B. Hölderlin et Heidegger. Recherche de la relation entre poésie e pensée. Trad. François Fédier. Paris: Presses Universitaires de France, 1959.

ANAXIMANDRO, PARMÊNIDES, HERÁCLITO. Os Pensadores Originários. Petrópolis: Vozes, 1991.

ARISTÓTELES, Poética. Capítulo XI. São Paulo: Abril Cultural. 1973.

BEAUFRET, J. Hölderlin e Sófocles. Rio de Janeiro: Jorge Zahar, 2008.

CAMPOS, H. A palavra vermelha de Hoelderlin. In: A arte no horizonte do provável. São Paulo: Perspectiva, 1977.

CÍCERO, A. O destino do homem. In: NOVAES, Adauto (org.). Os poetas que pensaram o mundo. São Paulo: Companhia das Letras, 2005.

DASTUR, F. Hölderlin: Tragédia e Modernidade. In: HÖLDERLIN, F. Reflexões. Trad. Márcia de Sá Cavalcante e Antonio Abranches. Rio de Janeiro: RelumeDumará, 1994.

HEIDEGGER. Approche de Hölderlin. Paris: Gallimard, 1951.

HÖLDERLIN, F. Escritos filosóficos de Hölderlin. In: ROSENFIELD, K. (org.) Filosofia \& Literatura: o trágico. Rio de Janeiro: Jorge Zahar, 2001.

HÖLDERLIN, F. Elegias. Trad. Maria Teresa Dias Furtado. Lisboa: Assírio e Alvim, 1992.

HÖLDERLIN, F. Hölderlin e outros estudos. In: QUINTELA, Paulo. Obras Completas de Paulo Quintela . Vols II, III e IV. Lisboa: Calouste Guilbekian. 1999

HÖLDERLIN, F. Oeuvres. Bibliotèque de la Plêiade. Paris: Gallimard, 2004.

HÖLDERLIN, F. Reflexões. Trad. Márcia de Sá Cavalcante e Antonio Abranches. Rio de Janeiro: Relume-Dumará, 1994.

HÖLDERLIN, F. Observações sobre Édipo e Antígona. In: ROSENFIELD, K. Antígona - de Sófocles a Hölderlin. Porto Alegre: L\&PM. 2000.

LACOUE-LABARTHE. P. Métaphrasis. Paris: Presses Universitaires de France. 1998.

MACHADO, R. Hölderlin e o afastamento do divino. In: $O$ nascimento do trágico: de Schiller a Nietzsche. Rio de Janeiro: Jorge Zahar, 2006.

MACHADO, R; SÜSSKIND, Tradução e notas. In: HÖLDERLIN, F. Observações sobre Édipo e Observações sobre Antígona. Rio de Janeiro: Jorge Zahar, 2008.

NAVILLE; FÉDIER. IN: HÖLDERLIN, Friedrich. Oeuvres. Bibliotèque de la Plêiade. Paris: Gallimard, 2004.

OTTO, Rudolf. O sagrado: os aspectos irracionais na noção do divino e sua relação com o racional. Trad. Walter O. Schlupp. São Leopoldo: Sinodal/EST; Petrópolis: Vozes, 2007.

ROSENFIELD, Kathrin. Antígona - de Sófocles a Hölderlin. Porto Alegre: L\&PM. 2000 .

ROSENFIELD, Kathrin. O estatuto teórico do "sentido estético" (a propósito de Hölderlin). In: Revista Analytica. São Paulo, vol 3, n.2, pps 157 - 195, 1998.

SZONDI, P. Ensaios sobre o trágico. Trad. Pedro Süssekind. Rio de Janeiro: Zahar Editores, 2004.

Solange Aparecida de Campos Costa, Universidade Estadual do Piauí, Rua Nossa Senhora de Fátima s/n, 64.202-220, Parnaíba - PI, Brasil. solange@phb.uespi.br

COSTA, Solange Aparecida de Campos. Vocação de poeta ou do trágico como tarefa da poesia em Hölderlin. Griot : Revista de Filosofia, Amargosa - BA, v.19, n.1, p.197-214, fevereiro, 2019. 